УДК: 331. 341. 1

JEL Classification: F 17

O. В. ЖУРАВЛЬОВ,

кандидат економічних наук,

доиент кафедри менеджменту зовнішньоекономічної діяльності, Наиіональна академія статистики, обліку та аудиту

\title{
Статистичне вивчення трансформаційних зрушень економіки України
}

В статті проведено економічну діагностику деяких важливих макроекономічних індикаторів України, цо відображають характер та швидкість економічноі трансформачіï. Запропоновано використання набору інституиійних змінних, ияо дозволив більи ретельно оцінити характер економічної трансформації в Украйні і виявити такі відхилення - трансформачія начіональної економіки відбувасться на різних швидкостях. Поряд із традиційними зруиеннями в структурі ВВП (домінування частки послуг) все ұще спостерігається незначний статистичний вплив паких важ-ливих інститучійних категорій як рівень політичної глобалізачії, контроль корупиіі, рівень захищеності прав власності, верховенства права, а також рівень сочіальноі глобалізаиії.

Ключові слова: економічна трансформачія, начіональна економіка, зовніиній борг, інфляиія, інституиійне середовище, регресійне моделювання.

Постановка проблеми. В сучасних умовах іманентних трансформацій особливий дослідницький інтерес представляють країни подвійної периферії. До цієї категорії, на жаль, й досі входить Україна. Пострадянська трансформація проходила під впливом багатьох факторів і на різних швидкостях, що призвело до різної швидкості трансформації і проблеми залежності від інституційної траскторій.

В період з початку 2014 р. Україна опинилася у важкому економічному і фінансовому стані, шо було спричинено низкою факторів політичного і економічного характеру. Автори аналітичної доповіді Національного інституту стратегічних досліджень [1] наполягають, що "тектонічний злам, який відбувся в українському суспільстві наприкінці 2013 - початку 2014 року, поза сумнівом, став вододілом початку нової доби. Надати повну та об'єктивну характеристику цієї доби можна буде лише в історичній перспективі, коли буде зрозумілим реальний баланс здобутків та втрат, ризиків і шансів, визначиться траєкторія розвитку суспільства, яке пройшло через випробування та трансформацію Майданом 2014 року” [1, с. 3].

Ми погоджуємось із цією тезою та хотіли б зазначити, що українська економічна система вступила у фазу іманентної системної кризи та вимагає нових теоретикометодологічних підходів для підготовки макроекономічних сценаріїв подальшого розвитку з урахуванням цивілізаційно-циклічних коливань економіки, геоекономічних та геополітичних зрушень в регіоні Східносвропейського порубіжжя (Білорусь, Україна, Молдова, країни Балтії).

Аналіз останніх досліджень та публікацій. Статистичне моделювання та економіко-математична оцінка трансформації економіки України в умовах глобалізації досліджувалося в працях таких авторів як О. Васєчко, О. Гончар, І. Журба, В. Захожай, І. Калачова, Р. Кулінич, Л. Момотюк, О. Осауленко, Н. Парфенцева, В. Попова, М. Пугачова, В. Швець та інші.

Разом із тим, досі не дослідженим $є$ саме моделювання інституційного середовища та його впливу на економічне зростання і швидкість трансформації.

Метою дослідження $\epsilon$ проведення економічної діагностики трансформаційних зрушень економіки України з використанням елементів статистичного моделювання.

Викладення основного матеріалу дослідження. Зрозуміти, що насправді відбулося в Україні, - вже означає розпочати шлях до оновленого суспільства, а також

w О. В. Журавльов, 2017 
запобігти повторенню подібних криз у майбутньому [1, с. 3]. Саме це спонукає вченихекономістів до нових наукових пошуків оптимальної моделі для України.

Темпи зростання української економіки в період з 2003 до 2016 рік є відображенням якості економічної політики (рис. 1).

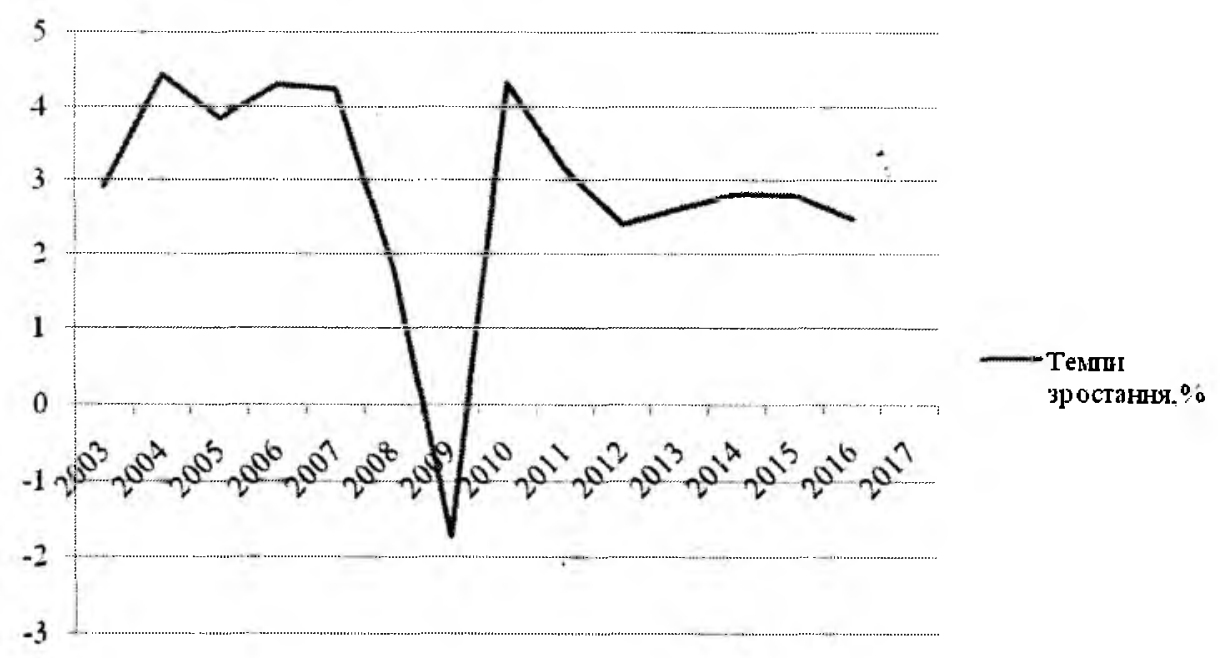

Рис. 1. Зміни темпів зростання ВВП України, \%

Джерело: побудовано за даними [2]

Така динаміка була обумовлена зовнішньою кон'юнктурою світових ринків на основні товари українського експорту, зростанням сукупного попиту всередині України, масовим кредитуванням споживачів українськимй банками і збільшенням частки "токсичних" кредитів у структурі банківської системи.

Зміни у структурі секторів національної економіки у створенні ВВП представлено на рис. 2.

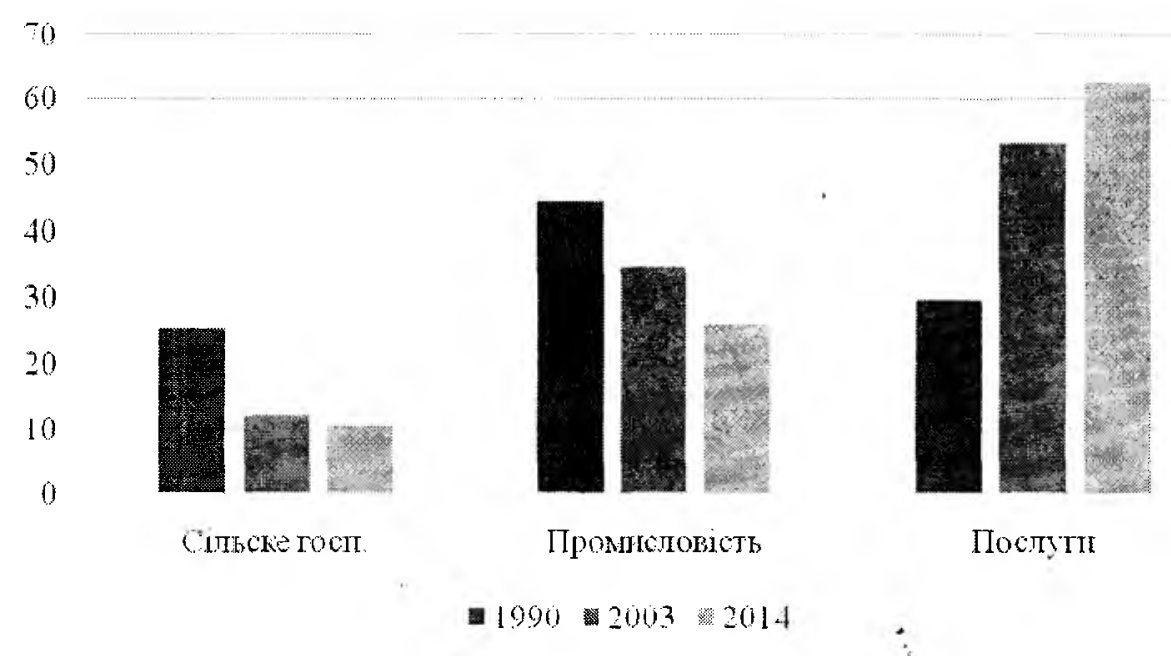

Рис. 2. Зміни структури ВВП України, \%

Джерело: побудовано за даними [2]

Загальна динаміка свідчить про природний процес економічної трансформації, який передбачає перехід до ринкової моделі з найбільшою часткою послуг та найменшою часткою сільського господарства.

Такий економічний підйом супроводжувався високим зростанням інфляції (рис. 3). 


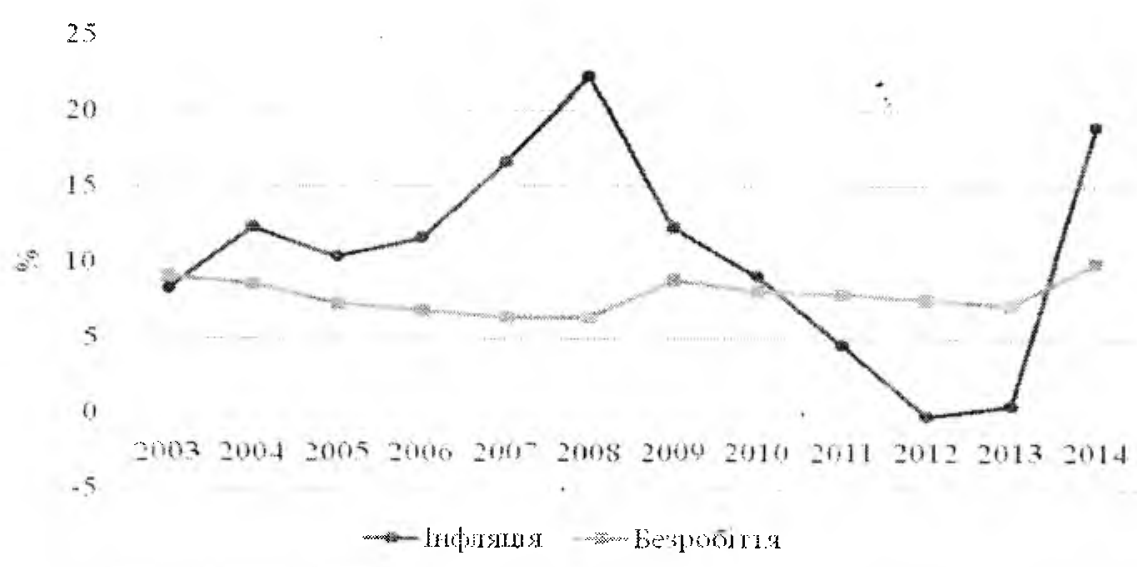

Рис. 3 Динаміка інфляції і безробіття в Україні, \%

Джерело: побудовано за даними [2]

Разом із тим, рівень безробіття в Україні протягом тривалого періоду часу коливається в межах 7-9\% i, як видно з графіку на рис. 3, майже не залежить від рівня інфляції.

П. В. Круша вважає, що для України коефіцієнт монетизації варіюється у межах 50\% [3]. Отже, можна вважати, що рівень монетизації національної економіки є достатнім у період 2004-2008 pp. (рис. 4). Це також пояснює інтенсивне макроекономічне зростання в Україні.

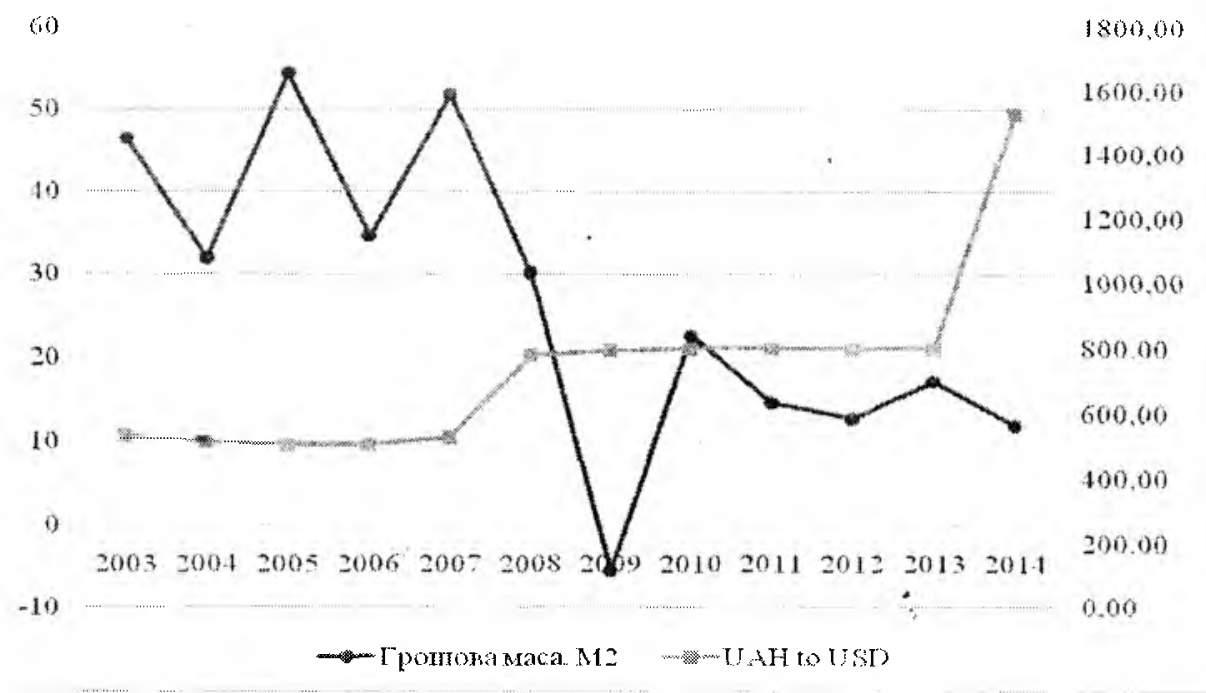

Рис. 4. Динаміка зміни грошової маси (\%) та курс української гривні до долара США (за 100 грн)

Джерело: побудовано за даними [2]

Традиційно вразливим для української економіки є валютний курс гривні до долару. Відносно стабільний курс гривні в період після девальвації 2008 р. тримався до кінця 2013 р., що дозволило українським урядам поступово знижувати інфляцію. Однак протягом усього 2014 р. українська валюта зазнавала постійних шоків.

На думку С. О. Якубовського, одним із факторів, що погіршує ситуацію на валютному ринку поряд із АТО у Східних областях України, є спекуляції великих фінансовопромислових груп (ФПГ), зокрема групи “Приват”. "Приватбанк” ще в квітні 2014 р. отримав від держави рефінансування на суму понад 20 млрд грн., і йому вигідно, щоб 
на момент повернення боргу курс гривні відносно долара був якомога нижче. Великий бізнес, побоюючись впливу І. Коломойського на економіку країни, відмовляється завозити в Україну валюту за експортними контрактами. Також проф. С. О. Якубовський зазначає, що після того, як на парламентських виборах 2014 р. підконтрольні Коломойському "Самопоміч" та "Народний фронт" за партійними списками набрали більше голосів, ніж Блок Петра Порошенка, здатність Президента впливати на економічну ситуацію в країні стала обмеженою [4].

Сучасна економічна ситуація в Україні й надалі зумовлюватиме зростання валового зовнішнього боргу України. Цей процес розпочався ще наприкінці 2008 р., і відтоді рівень боргу досягає критичних значень для трансформаційних економік.

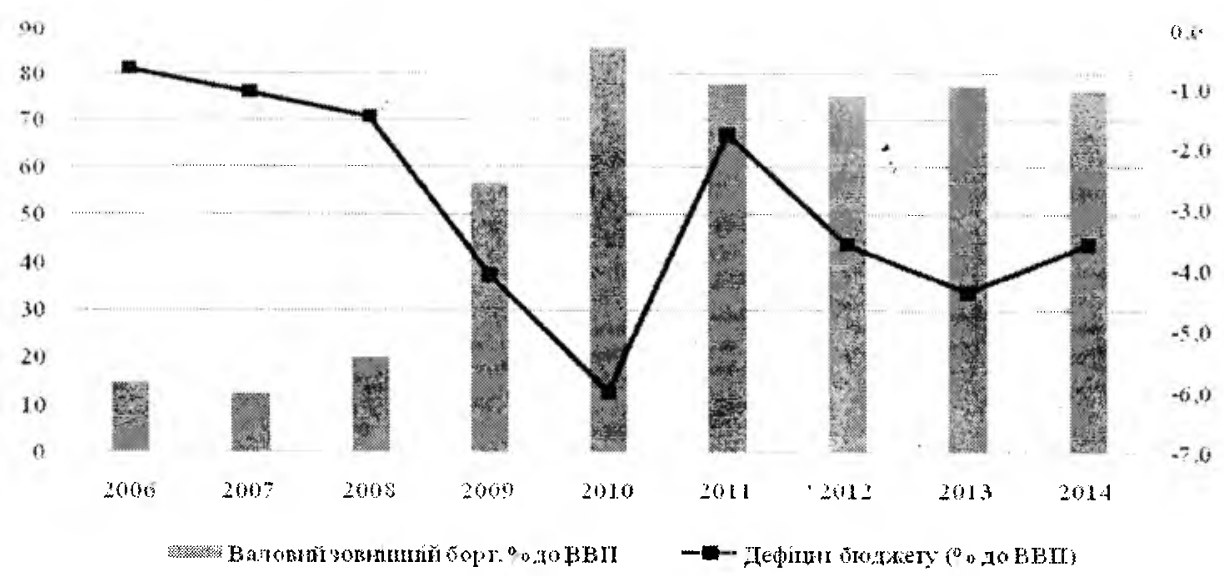

Рис. 5. Зростання валового зовнішнього боргу Украйни та дефіцит державного бюджету, \% до ВВП

Джерело: побудовано за даними [2]

В. О. Шевчук підкреслюе, “що помірне збільшення зовнішнього боргу, що супроводжується високою динамікою економічного зростання на інвестиційній основі та незначною інфляцією, зазвичай не передбачає макроекономічних дисбалансів. Необхідність обмеження зовнішніх запозичень банківської системи зокрема та зовнішнього боргу загалом видається очевидною з погляду на необхідність поліпшення сальдо поточного рахунку, зниження відсоткової ставки та гальмування інфляції. Проте потрібно врахувати, що урядові запозичення сприяють збільшенню інвестицій і не мають виразного інфляційного впливу” [5].

Разом із тим, на нашу думку, слід очікувати подальшого збільшення валового зовнішнього боргу України.

В структурі зовнішнього боргу України (рис. 6) 54\% припадає на інші сектори, що свідчить про слабкий контроль 3 боку держави за нарощуванням заборгованості великих приватних фінансових груп в Україні [2].

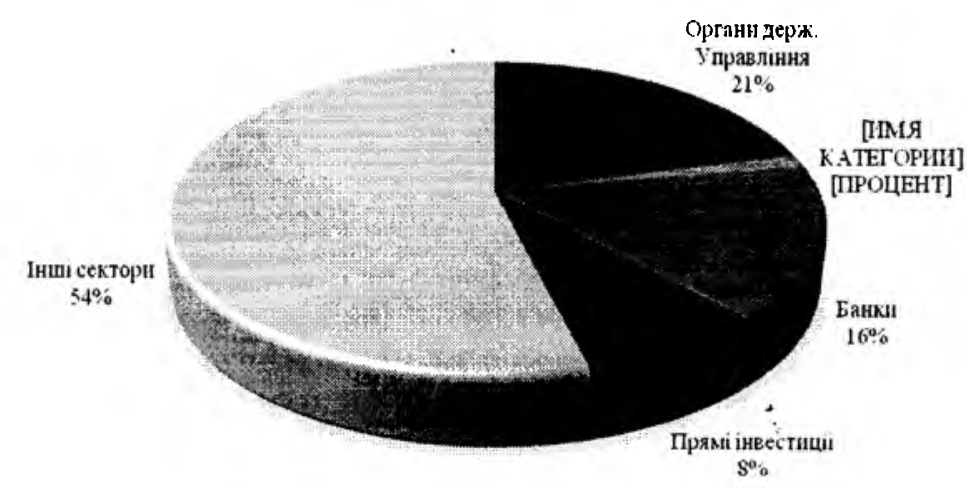

Рис. 6. Структура зовнішнього боргу України (2016р.)

Джерело: побудовано за даними [2]

\begin{tabular}{ll}
\hline SCIENTIFIC BULLETIN OF THE NATIONAL ACADEMY \\
OF STATISTICS, ACCOUNTING AND AUDIT, 2017, № 4
\end{tabular}


На думку С. О. Якубовського, головною причиною низької фінансової стійкості України стали бюджетні дефіцити, надходження дешевих зовнішніх кредитних ресурсів для приватного сектору та використання банківськими установами процентного валютного арбітражу, що, стимулюючи внутрішній попит, призводило як до зростання цін, так і до збільшення зовнішнього боргу країни [6].

Одним із факторів накопичення зовнішнього боргу є іманентність зростання витрат домогосподарств (рис. 7).

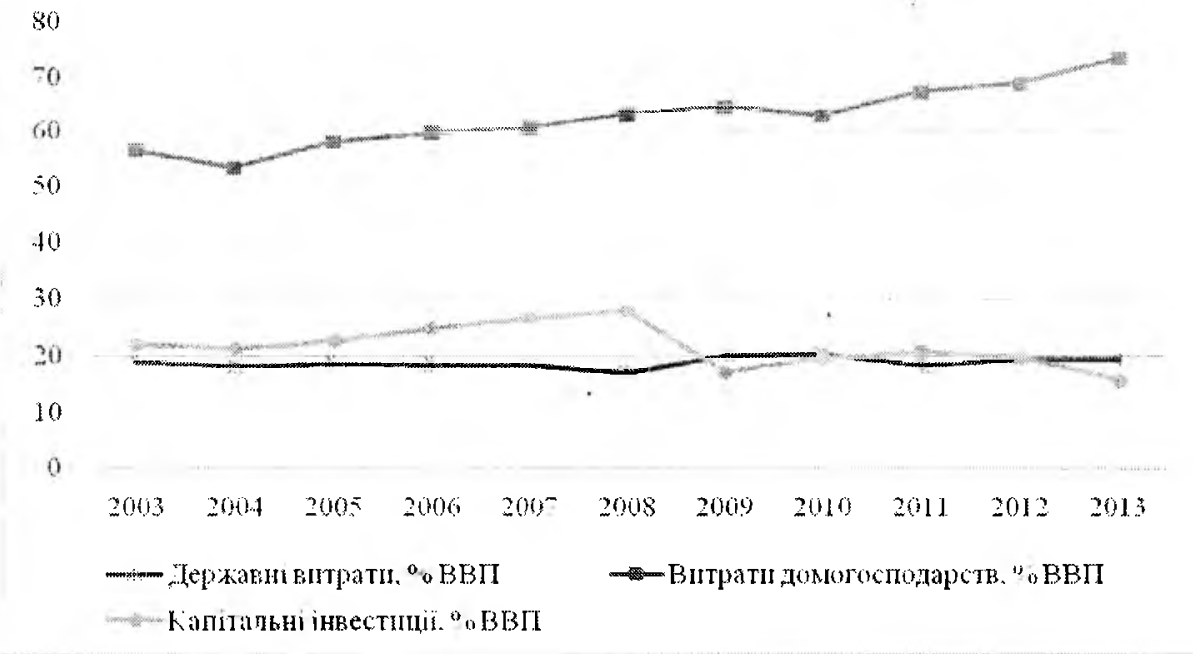

Рис. 7. Динаміка витрат в Украйні, \% ВВП

Джерело: побудовано за даними [2]

С. А. Буковинський зазначає: «Дозвіл на одержання населенням валютних кредитів у передкризовий період призвів до швидкого зростання фінансового ризику домогосподарств, який був підсилений доларизацією їхніх зобов'язань за відсутності джерел надходження валюти. Сформувався сильний кредитний важіль, який уможливив прискорене зростання споживання населення, але водночас прирікав його на стрімке падіння життєвого рівня в разі будь-якого зниження доходів» [7].

Наступним етапом нашого дослідження для досягнення мети статті - побудова та оцінка теоретичної моделі впливу інституційних факторів на економічне зростання в Україні.

На нашу думку, саме використання інституційної теорії дозволяє знайти новий підхід в економічній діагностиці траєкторії економічного розвитку України за останні 15 років та глибше зрозуміти трансформацію української економіки.

Статистичне моделювання проводилося в пакеті EViews 8 за розробленим автором алгоритмом.

В табл. 1 представлено перевірку статистичних даних на стаціонарність за методом Філіпса - Перрона, що дозволяє підготувати базу для оцінки регресійної моделі для України.

Табличя 1

Перевірка статистичних даних на стаціонарність

\begin{tabular}{|l|l|l|l|l|l|l|l|l|}
\hline \multicolumn{7}{|c|}{ Phillips-Perron test } & \\
\hline & proth & civillib & contrcor & econfre & ecglob & ecgrow & eduspend & energyuse \\
\hline $\mathrm{c}$ & $* * *$ & - & - & - & - & $* * *$ & - & - \\
\hline $\mathrm{ct}$ & $* * *$ & - & - & - & - & $* *$ & - & - \\
\hline $\mathrm{c}-$ diff & $* * *$ & $* *$ & $* *$ & $* * *$ & $* * *$ & $* * *$ & $* * *$ & $* * *$ \\
\hline $\mathrm{ct}-$ diff & $* * *$ & $* *$ & $* *$ & $* * *$ & $* * *$ & $* * *$ & $* * *$ & $* * *$ \\
\hline$* \mathrm{p}<0.10 ; * * \mathrm{p}<0.05 ; * * * \mathrm{p}<0.01 ;$ \\
\hline
\end{tabular}




\begin{tabular}{|c|c|c|c|c|c|c|c|c|c|}
\hline \multicolumn{10}{|c|}{ Phillips-Perron test } \\
\hline & femlab & \multicolumn{2}{|c|}{ Fiscalfr } & Gaspr & gdpppp & goveff & housecons & Humdev & Interusers \\
\hline c & - & \multicolumn{2}{|c|}{-} & - & - & - & - & - & - \\
\hline ct & - & \multicolumn{2}{|l|}{-} & - & - & - & - & - & - \\
\hline$c-$ diff & $* * *$ & \multicolumn{2}{|l|}{$* *$} & - & $* *$ & $* * *$ & $* * *$ & $* * *$ & - \\
\hline ct - diff & $* * *$ & \multicolumn{2}{|c|}{$* *$} & - & ** & $* * *$ & $* * *$ & $* * *$ & - \\
\hline \multicolumn{10}{|c|}{${ }^{*} \mathrm{p}<0.10 ;{ }^{* *} \mathrm{p}<0.05 ;{ }^{* * *} \mathrm{p}<0.01$} \\
\hline \multicolumn{10}{|c|}{ Phillips-Perron test } \\
\hline & lifeexp & \multicolumn{2}{|c|}{ Polglob } & polstab & prrights & rulelaw & \%serv & socglob & termstr \\
\hline c & - & \multicolumn{2}{|c|}{$* * *$} & - & $* *$ & - & $* * *$ & $* * *$ & - \\
\hline ct & - & \multicolumn{2}{|c|}{$* * *$} & - & $* *$ & - & $* * *$ & $* * *$ & - \\
\hline$c$ - diff & $*$ & \multicolumn{2}{|c|}{$* * *$} & $* * *$ & $* * *$ & $* *$ & *** & $* * *$ & $* * *$ \\
\hline ct - diff & $*$ & \multicolumn{2}{|c|}{$* * *$} & $* * *$ & $* * *$ & ** & $* * *$ & $* * *$ & $* * *$ \\
\hline \multicolumn{10}{|c|}{${ }^{*} \mathrm{p}<0.10 ;{ }^{* *} \mathrm{p}<0.05 ; * * * \mathrm{p}<0.01$} \\
\hline & tradeope & ess & Une & iployeme & & & & & \\
\hline $\mathrm{c}$ & - & & - & & & & & & \\
\hline ct & - & & - & & & & & & \\
\hline$c-$ diff & $-* * *$ & & $* * *$ & & & & & & \\
\hline ct - diff & $-{ }_{-* * *}$ & & $* * *$ & & & & : & & \\
\hline${ }^{*} \mathrm{p}<0.1$ & $; * * \mathrm{p}<$ & $05 ; *$ & $* \mathrm{p}$ & 0.01 & & & & & \\
\hline
\end{tabular}

Джерело: розрахунки автора

Всі нестаціонарні змінні взято в перших різницях. Результати оцінки моделі за методом найменших квадратів надано в табл. 2.

Для перевірки моделі на наявність одиничного кореню застосовано метод Брюша-Годфрі-існуюча нульова гіпотеза підвередила відсутність автокореляції в моделі (Prob. $F(3,2)=0,9317$ ).

Регресійна статистика для Украйни

Таблиця 2

\begin{tabular}{|c|c|c|c|c|}
\hline \multicolumn{4}{|c|}{ DependentVariable: ECONOMIC GROWTH } & \\
\hline \multicolumn{5}{|c|}{ Method: LeastSquares } \\
\hline \begin{tabular}{|c|} 
Variable \\
\end{tabular} & Coefficient & Std. Error & t-Statistic & Prob. \\
\hline D(CORRUPTION) & -9.12244 & 1.135399 & -0.563089 & 0.0034 \\
\hline D(ECONOMIC FREEDOM) & 3.945292 & 1.640535 & 1.767894 & 0.0518 \\
\hline D(ECONOMIC_GLOBILAZATION) & 1.396375 & 0.436114 & 3.201856 & 0.0328 \\
\hline D(EDUCATION SPENDING_GDP) & 0.147386 & 8.916616 & -2.071847 & 0.0070 \\
\hline D(FEMALE LABOUR FORCE) & 2.459205 & 1.200782 & 2.048002 & 0.1099 \\
\hline D(FISCAL FREEDOM) & 2.621415 & 1.523727 & -1.720397 & 0.0605 \\
\hline D(HOUSEHOLD CONS GDP) & 0.502966 & 0.105911 & 4.748935 & 0.0090 \\
\hline D(POLITICAL GLOBILIZATION) & 1.320555 & 1.817420 & 0.726610 & 0.5077 \\
\hline D(POLITICAL STABILITY) & 13.15292 & 6.568065 & 2.002556 & 0.1158 \\
\hline D(PROPERTY RIGHTS) & -1.306128 & 0.642491 & -2.032913 & 0.1118 \\
\hline D(RULE OF_LAW) & 66.27727 & 33.99895 & 1.949392 & 0.1230 \\
\hline D(SHARE OF_SERVICES) & 2.559632 & 0.872348 & 2.934188 & 0.0426 \\
\hline INTERNET USERS & 0.001966 & 0.105911 & 4.748935 & 0.0040 \\
\hline D(SOCIAL_GLOBILIZATION) & 1.549114 & 1.371444 & 1.129550 & 0.3218 \\
\hline R-squared & 0.916756 & \multicolumn{2}{|c|}{ Mean dependentvar } & 2.712000 \\
\hline Adjusted R-squared & 0.884733 & \multicolumn{2}{|c|}{ S.D. dependentvar } & 6.032439 \\
\hline S.E. ofregression & 2.002830 & \multicolumn{2}{|c|}{ Akaike infocriterion } & 4.217261 \\
\hline Sumsquaredresid & 16.04531 & \multicolumn{2}{|c|}{ Schwarz criterion } & 5.014547 \\
\hline Loglikelihood & -26.17561 & \multicolumn{2}{|c|}{ Hannan-Quinn criter. } & 3.373063 \\
\hline Durbin-Watson stat & 2.609718 & & & \\
\hline
\end{tabular}

Джерело: розраховано автором у пакеті EViews 8 


\section{СТАТИСтикА}

Рівень фіскальної свободи є запорукою трансформації інституційного середовища в Україні. В середньостроковій перспективі це значення буде збільшуватися і мати статистично позитивний вплив на економічне зростання.

Кількість користувачів мережі Інтернет у середньостроковій перспективі не дасть змогу збільшувати потенціал економічного зростання. На нашу думку, це результат саме того, що одночасно із збільшенням користувачів мережі Інтернет катастрофічно зменшується кількість населення.

Висновки і подальші дослідження. Протягом періоду 2003-2007 рр. економіка України зростала вражаючими темпами. Однак наразі країна переживає період серйозних випробувань, їй необхідно вирішувати проблеми структурного характеру, які ставлять під загрозу економічне зростання в довгостроковій перспективі. Виходом з ситуації, що склалася, мають стати реалізація потенціалу зростання перспективних галузей і підвищення продуктивності праці в масштабах країни. Однак особливу увагу слід звернути на перехід від екстрактних інститутів до інклюзивних. Ключовими факторами прискорення економіки України є посилення боротьби 3 корупцією та залучення інвестицій.

Нами проведено економічну діагностику деяких важливих макроекономічних індикаторів, які дозволяють зробити такі висновки: системна криза в економіці триває ще 32009 р., коли мала відкрита економіка Україна опинилася під впливом світової економічної кризи. Весь період економічної трансформації в Україні супроводжується високим рівнем інфляції, який не корелюе із рівнем безробіття, що коливається в межах 7-9\%. При цьому девальвація національної валюти стала перманентною. Все це непрямі докази високої частки “тіньовоі" економіки і низького рівня споживання. Водночас сигналом високого ризику є темпи зростання і структура державного боргу в Україні.

Нами запропоновано використання набору інституційних змінних, що дозволив більш ретельно оцінити характер економічної трансформації в Україні і виявити такі відхилення - трансформація національної економіки відбувається на різних швидкостях. Поряд із традиційними зрушеннями в структурі ВВП (домінування частки послуг) все ще спостерігається незначний статистичний вплив таких важливих інституційних категорій як рівень політичної глобалізації, контроль корупції, рівень захищеності прав власності, верховенства права, а також рівень соціальної глобалізації.

\section{Список використаних джерел}

1. Жаліло Я. А., Кононенко К. А., Яблонський В. М. та ін. Системна криза в Україні: передумови, ризики, шляхи подолання: аналіт. доп. / За заг. ред. Я. А. Жаліла. К.: НICД, 2014. 132 c.

2. Статистична інформація. Державна служба статистики України [Електронний pecypc]. URL: URL: http://www.ukrstat.gov.ua/.

3. Круша П. Національна економіка: підруч. / За ред. проф., к. е. н. П. Круша. К.: Каравела, 2008. $416 \mathrm{c}$.

4. Якубовський С. О., Журавльов О. В. Трансформація економічних систем країн Вишеградської групи: моногр. Одеса: ОНУ імені I. І. Мечнікова, 2016. 172 с.

5. Шевчук В. О. Макроекономічні ризики прискореної акумуляції зовнішнього боргу в економіці України // Стратегічні пріоритети. 2009. № 2(11). С. 159-166.

6. Якубовський С. О., Родіонова Т. А. Зовнішня заборгованість як фактор нестабільності банківської системи України // Постсоціалістичні країни в умовах світової фінансово-економічної кризи: зб. наук. праць конф. Ч. І. Одеса: Одеський національний університет імені I. 1. Мечникова, 2009. С. 23-26.

7. Буковинський С. Фінансова криза в Україні: вплив на розвиток економіки та деякі заходи з досягнення фінансової стабілізації // Фінанси України. 2010. № 11. C. 10-31. 


\title{
A. В. ЖУРАВЛЕВ, \\ кандидат экономических наук, дочент кафедры менеджмента внеинеэкономической деятельности, Науиональная академия статистики, учета и аудита
}

\section{Статистическое изучение трансформационных сдвигов в экономике Украины}

\begin{abstract}
В статье проведена экономическая диагностика некоторых важных макроэкономических индикаторов Украины, которые отражают характер и скорость экономической трансформачии. Предложено использование набора институчиональных переменных, который позволяет более тијательно оченить характер экономической трансформачии в Украине и выявить такие отклонения - трансформачия науиональной экономики происходит на разных скоростях. Наряду с традиционньими сдвигами в структуре ВВП (доминирование доли услуг) все еще наблюдается незначительное статистическое влияние таких важных институчиональных категорий как уровень политической глобализачии, контроль коррупчии, уровень зачиченности прав собственности, верховенства права, а такюе уровень сочиальной глобализации.

Ключевые слова: экономическая трансформауия, начиональная экономика, внеиний долг, инфлячия, институчиональная среда, регрессионное моделирование.

\section{O. V. ZHURAVLYOV, of Management Department, \\ National Academy of Statistics, Accounting and Audit}

PhD (Economics), Associate Professor
\end{abstract}

\section{Statistical Study of Transformation Changes in the Ukrainian Economy}

The article deals with the economic diagnostics of some important macroeconomic indicators of Ukraine that will reveal the nature and speed of the economic transformation.

During the period of 2003-2007, the Ukrainian economy grew at an impressive pace. However, at present, the country is undergoing a period of serious trials, it needs to address structural problems that endanger long-term economic growth. The way out of the current situation should be the realization of the potential for growth of advanced sectors and increase of productivity across the national economy. Special attention should be paid to the transition from extractive institutions to inclusive ones. Key factors in accelerating the Ukrainian economy are more vigorous fight against corruption and investment attraction.

A set of institutional variables is proposed, which allows for a more thorough assessment of the nature of economic transformation in Ukraine and detection of such deviations - transformation of the national economy occurs at different speeds. Along with the traditional shifts in the structure of GDP (the dominating share of services), there's still insignificant statistical effect of such important institutional categories as the level of political globalization, the control of corruption, the level of property rights protection, the rule of law, and the level of social globalization.

Key words: economic transformation, national economy, external debt, inflation, institutional environment, regression modeling.

Посилання на статтю:

Журавльов О. В. Статистичне вивчення трансформаційних зрушень економіки України // Науковий вісник Національної академії статистики, обліку та аудиту: 3б. наук. пр.. 2017. №4. С. 23-31. 